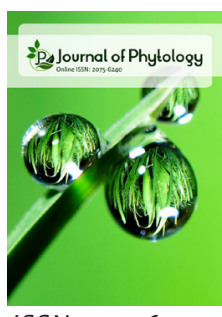

ISSN: $2075-6240$
Received: November 9, 2021 Revised: February 6, 2022 Accepted: February 17, 2022 Published: March 1, 2022

*Corresponding Author: Yasser Ahmed El-Amier E-mail: yasran@mans.edu.eg

\section{Vegetation analysis and species diversity of the invasive plant Heliotropium curassavicum growing naturally in heterogeneous habitats}

\author{
Marium Hamdy, El-Sayed F. El-Halawany, Ashraf Elsayed, \\ Yasser A. El-Amier* \\ Botany Department, Faculty of Science, Mansoura University, 35516, Mansoura, Egypt
}

\begin{abstract}
Heliotropium curassavicum is an invasive annual weed plant that spreads quickly, especially on disturbed saline soils and coastal locations in arid and semiarid habitats. This study aimed to assess the vegetation composition of the invasive plant H. curassavicum. The soil factors and associated species of this plant were studied in natural coastal desert habitats (northern Nile delta coast) and inland habitats (farrow land and canal bank habitats). The floristic composition revealed the occurrence of 109 species (67 annuals, 2 biennials and 40 perennials) belonging to 86 genera and related to 29 families. Asteraceae, Poaceae, Chenopodiaceae, and Fabaceae (53.21\% of all species reported) are the most abundant families. Therophytes and cryptophytes are the mainly abundant life forms and the Mediterranean chorotype is the most representative. The cluster analysis of stands expressed four vegetational groups (A, B, C and D). The most dominant species with group A was Polypogon viridis, with group B was H. curassavicum, with group C (the largest one) was Cynodon dactylon and H. curassavicum and with group D was Phragmites australis. Diversity indices expressed more richness and evenness of vegetation group B (H. curassavicum communities). The major soil factors influencing the studied invasive species are soil texture, WHC, organic carbon, cations $\left(\mathrm{Na}^{+}, \mathrm{K}^{+}, \mathrm{Ca}^{++}\right.$, and $\left.\mathrm{Mg}^{++}\right)$, and SAR.
\end{abstract}

KEYWORDS: Heliotropium curassavicum, Invasiveness, Biodiversity, Ecology, Edaphic factor

\section{INTRODUCTION}

Invasive plants have been identified as one of the most severe environmental issues globally (Barney et al., 2013). In Egypt, the growing population necessitates the expansion of agricultural land. This has been accomplished in recent decades by the reclamation of arid regions (Hegazy et al., 2004). Human intervention enforces weedy plants to displace native plants in the reclaimed regions, that are considered as transitional habitats between old cultivated lands and deserts (Baessler \& Klotz, 2006). The involvement of bioactive phytochemical constituents (allelochemicals) into chemical weapons of invasion is one of the processes of plant invasion (Zheng et al., 2015). Allelochemicals are a class of beneficial secondary metabolites that includes phenolic acids, glucosinolates, flavonoids, and essential oils (Einhellig, 1995; El-Amier et al., 2014b).

The major element influencing the quantity of natural vegetation in deserts is anthropogenic activity (El-Amier \&
Abd El-Gawad, 2017). Roads and railways construction are examples of activities that have a direct influence on existing habitats, such as deterioration and/or fragmentation, as well as an indirect influence on vegetation (Spellerberg, 1998; Jackson, 2000). Many researchers described plants communities and vegetation-environment interactions in Egypt's Nile Delta (ElAmier et al., 2014a; El-Amier \& El Hayyany, 2020).

Egypt possesses more than 3500 kilometers of coasts on the Mediterranean and Red Seas. Egypt's Mediterranean coastline area stretches for roughly $970 \mathrm{~km}$ from Sallum eastward to Rafah, with mean width of 20- 25 kilometers in the northernsouthern direction (Zahran \& Willis 2009). Higher erosion, water logging and soil salinization are all major concerns in Egypt's coastal areas, as are anthropogenic activities such as unplanned village building and ecosystem deterioration (El-Amier \& Abd El-Gawad, 2017). Moreover, the Nile Delta occupies $2 \%$ of its geographical areas and $63 \%$ of all agricultural lands $\left(\sim 29,600 \mathrm{~km}^{2}\right)$ is Egypt's most heavily used region, with $41 \%$ of the population (Negm et al., 2016). 
Heliotropium curassavicum (salt heliotrope) is an annual plant of the family Boraginaceae that is native to India, America, Hawaii, and Argentina, but considered as invasive plant in Africa, Europe, and Asia (Al-Shehbaz, 1991). It is an invasive species in Egypt's northern Mediterranean coastal area (Hegazy et al., 2008; Abd-ElGawad et al., 2019), and it has recently been discovered colonizing damaged habitats into the Nile Delta (Note from the author). This plant possesses the capability to reproduce vegetatively and sexually, allowing its colonization to a variety of environments (Hegazy, 1994). Plant bioactive components vary in response to changes in environmental circumstances (Elshamy et al., 2019; Abd-ElGawad et al., 2020), which is thought to be an adaptation mechanism since these bioactive chemicals allow plants to invade and colonize new environments (Zheng et al., 2015).

Invasive species continue to pose a significant threat to a variety of biological systems and species diversity across the world. Therefore, vegetation studies on invasive weed offer the quantitative data needed to design comprehensive weed community management plans, as well as the baseline data needed to track any changes in the weed flora (Frick \& Thomas, 1992; Gadallah et al., 2019). However, the vegetation composition and available data on invasive species in Egypt are still insufficient. The current study looks at the vegetation in the Nile Delta that is dominated by Heliotropium curassavicum. The major goal is to investigate the variety of vegetation and species in invasive plant communities in relation to habitats types.

\section{MATERIALS AND METHODS}

\section{Study Area}

The studied area was separated into two groups: coastal desert (represented by Delta Coast) and inland habitat (represented by farrow land and canal bank) (Figure 1). The Egyptian Mediterranean coastal desert is divided into three regions: western, delta, and eastern. The Deltaic Coast is defined by the occurrence of three shallow lakes that receive most of the Nile Delta's drainage water. This section stretches for roughly $200 \mathrm{~km}$ from Abu-Quir $\left(31^{\circ} 19^{\prime} 27.5^{\prime \prime} \mathrm{N} 30^{\circ} 04^{\prime} 00.6^{\prime \prime} \mathrm{E}\right)$ to Port-Said $\left(31^{\circ} 16^{\prime} 09^{\prime \prime} \mathrm{N} 32^{\circ} 18^{\prime} 19.1^{\prime \prime} \mathrm{E}\right)$. The Nile Delta's coastal zone featured new cities construction, desert reclamation, and agricultural activities, among other things. In numerous sites, the growth of the invasive plant $H$. curassavicum is associated with cultivated lands (such as Barley, maize, tomato, sesame, and watermelons).

On the other hand, the Mediterranean Sea's impact modifies the climate along Egypt's north coast. Despite the fact that the climate of the Nile delta shore is comparable to that of the western and eastern Mediterranean, there is a distinction in vegetation composition. In addition to seawater, it is impacted by leakage water from the Damietta and Rosetta River Nile branches in addition to the northern lakes (Zahran \& Willis, 2009).

\section{Vegetation Analysis}

During the months of March and May in 2019 and 2020, 45 sampling stands ( 10 meters $\times 10$ meters) were randomly chosen

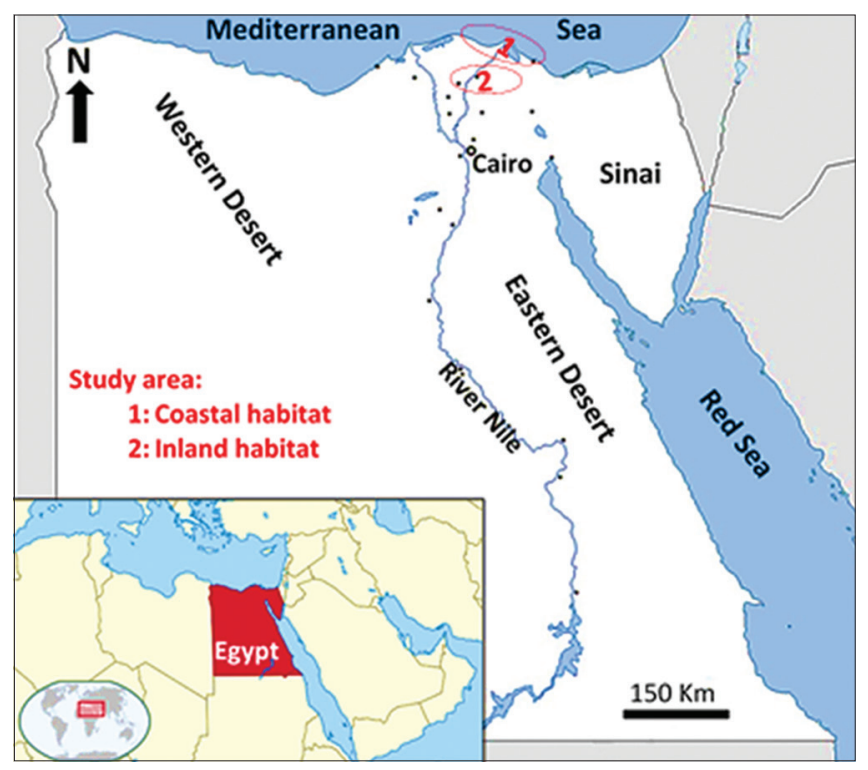

Figure 1: Map demonstrating the Nile delta and the studied area

to express a broad scale of physiographic and environmental variability in the coastal and inland environments (Nile Delta). In each plot, the density and cover of plants were recorded as adopted by Shukla and Chandel (1989). For each plant species, relative density, cover and importance values (IV) were calculated. To represent the H. curassavicum in the study sites, a floristic list was obtained from the 45 sites: 29 along the Deltaic Mediterranean coast and 16 from the inland habitats. Tackholm (1974) and Boulos (1999-2005) are used to identify the species reported. According to Zohary (1966 and 1972), the chorology of the plant species was localized and life forms were described in harmony with the scheme of Raunkięr (1934 - 1937).

\section{Plants Diversity}

The Shannon Wiener diversity index $(\mathrm{H})$, Simpson Diversity Index (D), and Shannon evenness index (E) were determined for each community and used to compute species richness and evenness:

$$
\begin{gathered}
H=\sum_{i=1}^{s} P_{i} \ln \left(P_{i}\right) \\
D=\frac{\sum_{i}\left[n_{i} \times\left(n_{i}-1\right)\right]}{[N \times(N-1)]} \\
E=\frac{H}{\ln s}
\end{gathered}
$$

$P i=n i / N, n i=$ the number of stands and $N$ is the total number of species.

\section{Soil Analysis}

Three soil samples were obtained at depths of $0-20 \mathrm{~cm}$ from each of the 45 study sites. The samples were spread sheets of paper then air dried. For each soil sample, a soil solution (1:5) was produced. 
Piper's (1947) method was used to evaluate the texture, water holding capacity (WHC), porosity, organic carbon, and sulphate content of the soil. The electrical conductivity, $\mathrm{pH}$, calcium carbonate and chloride were estimated according to the assay described by Jackson (1962). Titration with $0.1 \mathrm{~N} \mathrm{HCl}$ was used to determine carbonate and bicarbonate (Pierce et al., 1958). Sodium and potassium cations were detected by a Flame Photometer (Model PHF 80 Biologie Spectrophotometer), while the levels of calcium and magnesium were measured by atomic absorption spectrometer (Perkin-Elmer, Model 2380 USA) (Allen et al., 1974).

\section{Statistical Analysis}

The vegetation associated with $H$. curassavicum was classified and ordinated by TWINSPAN analysis using the Community Analysis Package (CAP) software application (version 2.3) (Hill $\&$ Smilauer, 2005). The relationship between vegetation and soil gradients was examined using Canonical Correspondence Analysis (CCA) (Ter Braak, 1988). Soil analyses results were analyzed by ANOVA and Least Significant Difference (LSD) at 0.05 probability level using COSTAT 6.3 program. Using SPSS 16 for Windows, the linear correlation coefficient (r) was computed to assess the relationship between the obtained soil parameters and the community variations.

\section{RESULTS AND DISCUSSION}

\section{Floristic Analysis}

One hundred and nine plant species (67 annuals, 2 biennials and 40 perennials) from 86 genera and 29 families were listed in this study (Appendix 1). During the winter season, this region of the country received the most rain (Zahran and Willis, 2009). Annual plants possess higher reproduction capacity in addition to their morphological, ecological, and genetic plasticity (Grime, 1979; Kowarik, 1985). In accordance with the literature, Asteraceae, Poaceae, Chenopodiaceae, and Fabaceae $(22,18,11 \& 7$ species, respectively), Brassicaceae and Polygonaceae (6 species each), and Euphorbiaceae (4 species) were the most numerous groups (4 species). They made up $67.89 \%$ of all species reported and account for the majority of the floristic composition in this area; whereas the nine families contain $20.18 \%$ of the species and 13 monospecific families. In the Mediterranean and Northern Africa flora, these are the most prevalent families (Abd El-Gawad \& Shehata, 2014; El-Amier et al., 2014a). Together, the Asteraceae and Poaceae families are the world's biggest and most diverse flowering plant family (Walters \& Keil, 1996; Christenhusz \& Byng, 2016).

Taxonomic diversity in the studied area is 1.27 for species/ genera ratio and 2.97 for genera/families. In general, there is a small family size: just three families contain more than ten species, while 26 have fewer than ten. Clearly, genus Euphorbia, Amaranthus, and Cyperus contain the highest number of species (4, 3 and 3 species, respectively), while Launaea, Zygophyllum, Bassia, Carduus, Conyza, Mesembryanthemum, Plantago, Polypogon, Rumex and Senecio genera contain only two species (Appendix 1).
Seventy eight species ( 32 perennials, 2 biennials and 53 annuals) were recorded in the Deltaic Mediterranean coastal desert and 58 species (20 perennials and 38 annuals) in the inland habitats (roadsides and furrow land in the Nile Delta). Convolvulus arvensis, Cynanchum acutum, Cynodon dactylon, Imperata cylindrica, Lolium perenne, Phragmites australis, Phyla nodiflora and Symphyotrichum squamatum were the most abundant perennial species associated with $H$. curassavicum in the two habitats while, Echinopus spinosus, Zygophyllum aegyptium, and Zygophyllum albam were the perennial species found in the coastal desert that were linked with the examined plant. Each of these species recorded higher importance values (IV) (Appendix 1). The number of invasive species in the Nile Delta is higher than in Egypt's other phytogeographical zones. This may be due to the fact that the Nile area has a long history of human civilization, and the indigenous peoples of Egypt have had the time and opportunity to alter the natural vegetation via their agricultural operations. The invasive species, on the other hand, do poorly in the Red Sea and Gebel Elba areas, owing to their distance from heavy human effect, as well as their dry habitat (Shaltout et al., 2016).

Therophytes made up the bulk of the species observed $(60 \%$ of the total species), followed by cryptophytes (17.39\%), hemicryptophytes $(10.43 \%)$, and chamaephytes $(8.70 \%)$, with nanophanerophytes accounting for $2.61 \%$. Therophytes were the most dominant species among the recorded life forms (Appendix 1) and appears to be a response to hot-dry climate, topographic variability and biotic effect that distinguish the study area (Heneidy \& Bidak, 2001). At the time, cryptophytes are also the most common life form (Appendix 1). This could be described in terms of plant habits, as nearly all of these plants are rhizomatous, which are thought to be more resistant to breakdown when submerged in water. The same conclusions have almost been obtained by El-Demerdash (1984), Shaltout et al. (1994) and El-Amier et al. (2021). Figure 2 depicts the life forms of the associated species with the investigated plant in the studied habitats.

\section{Chorological Affinities of the Associated Vegetation}

According to a chorological study, the studied habitats have the most Mediterranean elements (Deltaic coast: 53 species = $48.62 \%$, and interior habitat: 21 species $=19.27 \%$ ) (Table 1$)$. The Mediterranean chorotype of the studied flora's wide reveals the Mediterranean climate of the study area. The obtained results are consistent with the findings of the majority of comparable investigations (Barakat et al., 2014; El-Amier, 2016; El-Amier \& Abd El-Gawad, 2017). Cosmopolitan and SaharoSindian elements accounted for 11 and 7 species of the total (10.09\% and 6.42\%, respectively) in the Deltaic coast. While, Cosmopolitan and Pantropical have 17 and 9 species (15.60\% and $8.57 \%$, respectively) in inland habitats (Table 2). In the Deltaic coast, cosmopolitan and Saharo-Sindian elements accounted for 11 and 7 species $(10.09 \%$ and $6.42 \%$ of the total species), respectively. Whereas, in inland habitat, Cosmopolitan and Pantropical had 17 and 9 species $(15.60 \%$ and $8.57 \%$, respectively) (Table 1 ). 


\section{Classification of the Vegetation}

At the second level of classification, TWINSPAN analysis techniques identified four primary vegetational groups, with the different overall numbers of species across groups (Figure 3 and Table 2). Each detected vegetation category was given a name based on the dominant species. Two of the documented species, C. dactylon and P. australis, were found to possess a wide ecological distribution range and to be present in all of the identified vegetation types.

\section{Group (A): Polypogon Viridis Group}

29 species were identified in this group from 4 stands in the inland habitats (roadsides and furrow land in the Nile Delta) except site 22; it is linked to H. curassavicum as important species, with a mean species richness of 3.21 species/stand, Simpson index of 0.97 and Shannon diversity index of 0.87 (Table 2). These stands were in soils with higher content of silt, clay, WHC, $\mathrm{OC}$ and $\mathrm{CaCO}_{3}$ and moderate content of cations and anions (Table 3). The other abundant species include Amaranthus hybridus (indicator species), Euphorbia heterophylla, Bidens pilosa and Sonchus oleraceus. The other indicator species in this group was Bromus diandrus.

\section{Group (B): Heliotropium Curassavicum Group}

54 species were identified in this group from 15 stands in the inland and Deltaic Mediterranean coastal strip habitat. It has a mean species richness of 3.69 species/stands, Simpson index of 0.97 and Shannon diversity index of 0.89 (Table 2). These stands present in soil with higher electrical conductivity and moderate contents of the other examined soil variables

Table 1: Number of species and percent of the floristic categories in the coastal and inland habitats

\begin{tabular}{|c|c|c|c|c|c|c|}
\hline \multirow[t]{3}{*}{ Floristic categories } & \multirow{2}{*}{\multicolumn{2}{|c|}{ Study area }} & \multicolumn{4}{|c|}{ Phytogeographical regions } \\
\hline & & & \multicolumn{2}{|c|}{ Coastal } & \multicolumn{2}{|c|}{ Inland } \\
\hline & No. & $\%$ & No. & $\%$ & No. & $\%$ \\
\hline \multicolumn{7}{|l|}{ Worldwide } \\
\hline COSM & 19 & 17.43 & 11 & 12.64 & 17 & 29.31 \\
\hline NEO & 3 & 2.75 & 2 & 2.30 & 3 & 5.17 \\
\hline PAN & 9 & 8.26 & 5 & 5.75 & 9 & 15.52 \\
\hline PAL & 7 & 6.42 & 3 & 3.45 & 5 & 8.62 \\
\hline \multicolumn{7}{|l|}{ Pluriregional } \\
\hline $\mathrm{ME}+\mathrm{IR}-\mathrm{TR}+\mathrm{ER}-\mathrm{SR}$ & 14 & 12.84 & 12 & 13.79 & 7 & 12.07 \\
\hline $\mathrm{ME}+\mathrm{ER}-\mathrm{SR}+\mathrm{SA}-\mathrm{SI}$ & 2 & 1.83 & 2 & 2.30 & - & - \\
\hline ME+IR-TR + SA-SI & 6 & 5.50 & 6 & 6.90 & 3 & 5.17 \\
\hline \multicolumn{7}{|l|}{ Biregional } \\
\hline ME+IR-TR & 10 & 9.17 & 8 & 9.20 & 6 & 10.34 \\
\hline $\mathrm{ME}+\mathrm{SA}-\mathrm{SI}$ & 10 & 9.17 & 10 & 11.49 & 1 & 1.72 \\
\hline$M E+E R-S R$ & 3 & 2.75 & 3 & 3.45 & 1 & 1.72 \\
\hline$M E+P A L$ & 1 & 0.92 & 1 & 1.15 & 1 & 1.72 \\
\hline IR-TR + SA-SI & 3 & 2.75 & 3 & 3.45 & 1 & 1.72 \\
\hline IR-TR + S-Z & 1 & 0.92 & 1 & 1.15 & - & - \\
\hline$S A-S I+S-Z$ & 2 & 1.83 & 1 & 1.15 & 2 & 3.45 \\
\hline \multicolumn{7}{|l|}{ Monoregional } \\
\hline $\mathrm{ME}$ & 11 & 10.09 & 11 & 12.64 & 2 & 3.45 \\
\hline SA-SI & 7 & 6.42 & 7 & 8.05 & - & - \\
\hline AUST & 1 & 0.92 & 1 & 1.15 & - & - \\
\hline Total & 109 & 100 & 87 & 100 & 58 & 100 \\
\hline
\end{tabular}

(Table 3). Sporadic species included 17 species, of Apium leptophyllum, Calendula arvensis, Capsella bursa pastoris, Conyza bonariensis, Cornopus didymus, Cyperus articulates, Eclipta alba, Emex spinosa, etc (Appendix 1). The abundant species include Cynodon dactylon, S. oleraceus, P. nodiflora, Rumex dentatus and C. arvensis.

\section{Group (C): Cynodon Dactylon and Heliotropium Curassavicum Group}

This group showed higher diversity as it comprises 74 species identified from 23 stands, from the inland habitat and Deltaic Mediterranean coastal strip, with a mean species richness of 3.61 species/stands, Simpson index of 0.95 and

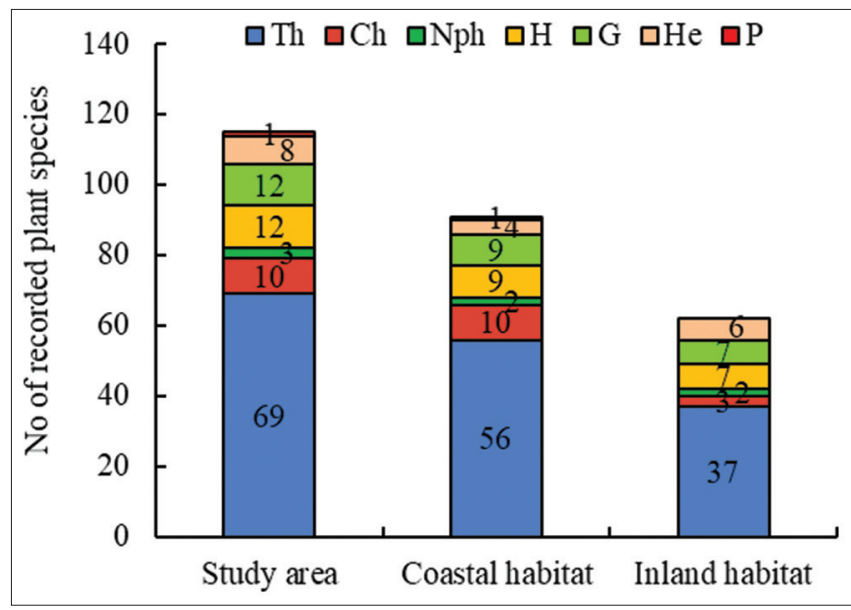

Figure 2: Plant life-form in the study area, and two habitats

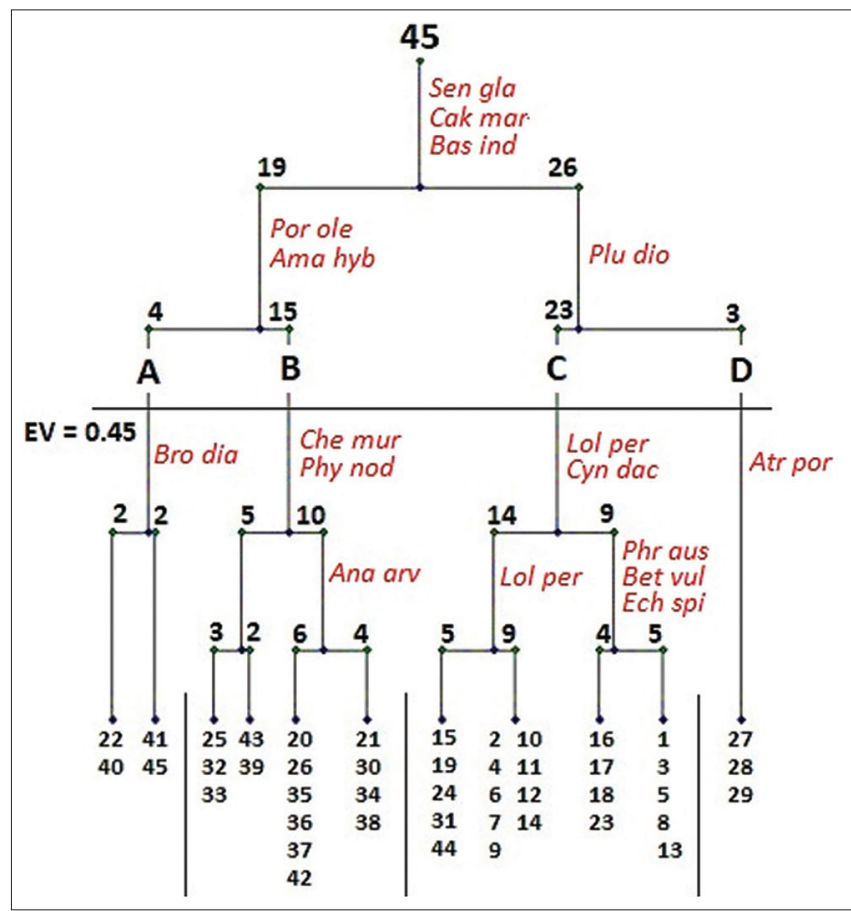

Figure 3: TWINSPAN dendrogram of 45 stands according to the importance value and the 4 vegetation groups (A-D) separated. EV: Eigen value 
Table 2: Plant diversity, dominant and important plant species of the tow studied habitats of Heliotropium curassavicum

\begin{tabular}{|c|c|c|c|c|c|c|c|}
\hline \multirow{2}{*}{$\begin{array}{l}\text { Vegetation } \\
\text { group }\end{array}$} & \multirow{2}{*}{$\begin{array}{c}\text { Stand } \\
\text { No. }\end{array}$} & \multirow{2}{*}{$\begin{array}{c}\text { Total } \\
\text { Species }\end{array}$} & \multicolumn{3}{|c|}{ Species Diversity Indices } & \multirow[t]{2}{*}{ Dominant species } & \multirow[t]{2}{*}{ Other important species } \\
\hline & & & Simposn & Shannon-Wienner & Shannon-evenness & & \\
\hline A & 4 & 29 & 0.97 & 3.21 & 0.87 & $\begin{array}{l}\text { Polypogon viridis } \\
(29.66 \pm 0.88)\end{array}$ & $\begin{array}{c}\text { Heliotropium curassavicum }(21.26 \pm 0.46) \\
\text { Amaranthus hybridus }(18.74 \pm 0.71) \\
\text { Euphorbia heterophylla }(12.92 \pm 1.44) \\
\text { Bidens pilosa }(12.11 \pm 0.82) \\
\text { Sonchus oleracous }(11.97 \pm 1.23)\end{array}$ \\
\hline B & 15 & 54 & 0.97 & 3.69 & 0.89 & $\begin{array}{l}\text { Heliotropium } \\
\text { curassavicum } \\
(25.02 \pm 0.33)\end{array}$ & $\begin{array}{l}\text { Cynodon dactylon }(18.71 \pm 0.84) \\
\text { Sonchus oleraceus }(8.13 \pm 0.87) \\
\text { Phyla nodiflora }(7.84 \pm 1.57) \\
\text { Rumex dentatus }(7.66 \pm 1.36) \\
\text { Convolvulus arvensis }(7.31 \pm 1.36)\end{array}$ \\
\hline C & 23 & 74 & 0.95 & 3.61 & 0.81 & $\begin{array}{l}\text { Cynodon dactylon } \\
(15.83 \pm 1.00) \\
\text { Heliotropium } \\
\text { curassavicum } \\
(15.60 \pm 0.36)\end{array}$ & $\begin{array}{l}\text { Zygophyllum albam }(11.33 \pm 1.69) \\
\text { Hordium murinum }(11.08 \pm 1.32) \\
\text { Cakile maritima }(10.09 \pm 0.98) \\
\text { Phragmites australis }(9.59 \pm 0.85) \\
\text { Senecio glaucus }(9.46 \pm 1.21)\end{array}$ \\
\hline D & 3 & 11 & 0.91 & 3.07 & 0.85 & $\begin{array}{l}\text { Phragmites australis } \\
\quad(45.26 \pm 0.44)\end{array}$ & $\begin{array}{c}\text { Arthrocnemum macrostachyum }(17.30 \pm 0.87) \\
\text { Atriplex portulacoides }(25.04 \pm 0.87) \\
\text { Cynodon dactylon }(18.56 \pm 1.73) \\
\text { Halocnemum strobilaceum } \\
(17.86 \pm 1.04) \\
\text { Heliotropium curassavicum } \\
(25.35 \pm 0.47) \\
\text { Pluchea dioscoridis }(23.48 \pm 0.24)\end{array}$ \\
\hline
\end{tabular}

Table 3: Mean values, standard error $( \pm S E)$ and ANOVA values of the soil parameters in the vegetation groups $(A-D)$ of the study area

\begin{tabular}{|c|c|c|c|c|c|c|}
\hline \multirow[t]{2}{*}{ Soil variable } & \multicolumn{4}{|c|}{ Vegetational group } & \multicolumn{2}{|c|}{ One-way ANOVA } \\
\hline & $\mathrm{A}$ & $B$ & C & $\mathrm{D}$ & F-value & P-value \\
\hline Sand (\%) & $51.62 \pm 7.23$ & $58.11 \pm 5.90$ & $86.30 \pm 4.04$ & $39.35 \pm 0.78$ & 10.99 & $0.0001 * * *$ \\
\hline Silt (\%) & $28.21 \pm 4.26$ & $25.91 \pm 3.75$ & $7.95 \pm 2.32$ & $38.64 \pm 0.46$ & 11.89 & $0.0000 * * *$ \\
\hline Clay (\%) & $20.18 \pm 2.99$ & $15.99 \pm 2.27$ & $5.75 \pm 2.03$ & $22.01 \pm 1.03$ & 8.98 & $0.0003 * * *$ \\
\hline Porosity (\%) & $32.88 \pm 0.44$ & $30.84 \pm 0.99$ & $39.33 \pm 1.57$ & $30.37 \pm 0.98$ & 17.52 & $0.0000 * * *$ \\
\hline WHC (\%) & $60.64 \pm 5.19$ & $51.87 \pm 4.05$ & $32.94 \pm 2.91$ & $53.27 \pm 2.27$ & 7.08 & $0.0011 * *$ \\
\hline $\mathrm{CaCO}_{3}(\%)$ & $7.19 \pm 0.67$ & $5.34 \pm 0.90$ & $3.66 \pm 0.61$ & $5.57 \pm 0.77$ & 5.59 & $0.0039 * *$ \\
\hline OC $(\%)$ & $4.38 \pm 0.78$ & $4.10 \pm 0.66$ & $1.14 \pm 0.44$ & $4.00 \pm 0.54$ & 5.12 & $0.0060 * *$ \\
\hline $\mathrm{pH}$ & $8.24 \pm 0.16$ & $8.20 \pm 0.12$ & $8.31 \pm 0.15$ & $7.56 \pm 0.03$ & 3.03 & $0.0461 *$ \\
\hline $\mathrm{EC} \mathrm{mS} \mathrm{cm} \mathrm{cm}^{-1}$ & $659.75 \pm 55.30$ & $814.27 \pm 99.87$ & $745.57 \pm 163.03$ & $790.67 \pm 43.40$ & 0.36 & $0.7859 \mathrm{~ns}$ \\
\hline $\mathrm{Cl}^{-}(\%)$ & $0.46 \pm 0.17$ & $0.50 \pm 0.15$ & $0.76 \pm 0.19$ & $0.13 \pm 0.00$ & 1.76 & $0.1786 n s$ \\
\hline $\mathrm{SO}_{4}^{--}(\%)$ & $0.48 \pm 0.10$ & $0.46 \pm 0.09$ & $0.55 \pm 0.12$ & $0.28 \pm 0.02$ & 0.87 & $0.4685 \mathrm{~ns}$ \\
\hline $\mathrm{HCO}_{3}^{-}(\%)$ & $0.26 \pm 0.02$ & $0.21 \pm 0.01$ & $0.48 \pm 0.38$ & $0.21 \pm 0.01$ & 0.86 & $0.4750 \mathrm{~ns}$ \\
\hline $\mathrm{Na}^{+}\left(\mathrm{mg} \mathrm{g}^{-1}\right)$ & $77.18 \pm 7.70$ & $101.18 \pm 14.44$ & $256.04 \pm 33.93$ & $41.75 \pm 2.77$ & 19.32 & $0.0000 * * *$ \\
\hline $\mathrm{K}^{+}\left(\mathrm{mg} \mathrm{g}^{-1}\right)$ & $54.64 \pm 9.20$ & $38.12 \pm 5.92$ & $75.21 \pm 5.97$ & $25.43 \pm 2.39$ & 5.24 & $0.0054 * *$ \\
\hline $\mathrm{Ca}^{++}\left(\mathrm{mg} \mathrm{g}^{-1}\right)$ & $53.52 \pm 7.67$ & $44.17 \pm 5.19$ & $142.19 \pm 17.02$ & $32.14 \pm 4.81$ & 20.44 & $0.0000 * * *$ \\
\hline $\mathrm{Mg}^{++}\left(\mathrm{mg} \mathrm{g}^{-1}\right)$ & $38.09 \pm 6.73$ & $32.42 \pm 4.68$ & $99.85 \pm 11.59$ & $22.34 \pm 1.28$ & 21.37 & $0.0000 * * *$ \\
\hline SAR & $11.58 \pm 0.55$ & $15.83 \pm 1.45$ & $22.46 \pm 2.01$ & $8.07 \pm 0.09$ & 15.32 & $0.0000 * * *$ \\
\hline PAR & $7.98 \pm 0.91$ & $5.88 \pm 0.59$ & $7.44 \pm 0.82$ & $4.84 \pm 0.18$ & 2.06 & $0.1282 \mathrm{~ns}$ \\
\hline
\end{tabular}

Shannon diversity index of 0.81 (Table 2). Sand, porosity, $\mathrm{pH}$, sodium, potassium, calcium, magnesium, chloride, bicarbonate and sulphate were at their highest levels in these stands (Table 3). Sporadic species comprised 47 species (or about $43.12 \%$ of the listed species in this group) that included Aegilops bicornis, Alhagi graecorum, Amaranthus graecizans, Carduus getulus, Carduus pycnocephalus, Carthamus tenuis, Cyperus capitatus and Launaea nudicaulis (Appendix 1). The abundant species in this group include Z. albam, Hordium murinum, Cakile maritima, P. australis and Senecio glaucus.

\section{Group (D): Phragmites Australis Group}

It is the smallest group, representing the Deltaic Mediterranean coastal strip habitat. It contains 11 species identified from three stands, with the lowest species richness of 3.07 species/stands, Simpson index of 0.91 and Shannon diversity index of 0.85 (Table 2). These sites were characterized by higher percentages of fine particles (silt and clay), $\mathrm{CaCO}_{3}$ and organic carbon, but the majority of soil variables tested were at lower levels in these stands (Table 3). The abundant species in this group include 
Arthrocnemum macrostachyum, Atriplex portulacoides, Cynodon dactylon, Halocnemum strobilaceum, Heliotropium curassavicum and Pluchea dioscoridis (Appendix 1).

\section{Sampling Sites Ordination}

Figure 4 depicts the DCA-generated sampled stands ordination. The TWINSPAN vegetation groups were highly distinct and had a coherent pattern of segregation on the ordination plane, meanwhile, the groups A and B split at the middle portion of the right side of the DCA diagram, that was obviously segregated along the two axes of DCA. The largest group, Group $\mathrm{C}$ is split on the left side. Group D stands are clearly separated on the lower side from the other groups along the two axes of the DCA diagram. It's worth noting that the strong parallels in floristic composition and natural habitats between the above-mentioned plant types may explain interspecific connections.

\section{Soil-vegetation Relationships}

Canonical Correspondence Analysis (CCA) was used for investigating the link between vegetation and soil characteristics. The CCA ordination biplot with vegetation groups (A-D) and the investigated soil parameters are shown in Figure 5. The phytodiversity of natural communities can be influenced by soil texture, salinity, and organic carbon (El-Sheikh, 1989; Pinke et al., 2010). In this study, soil texture, WHC, organic carbon,

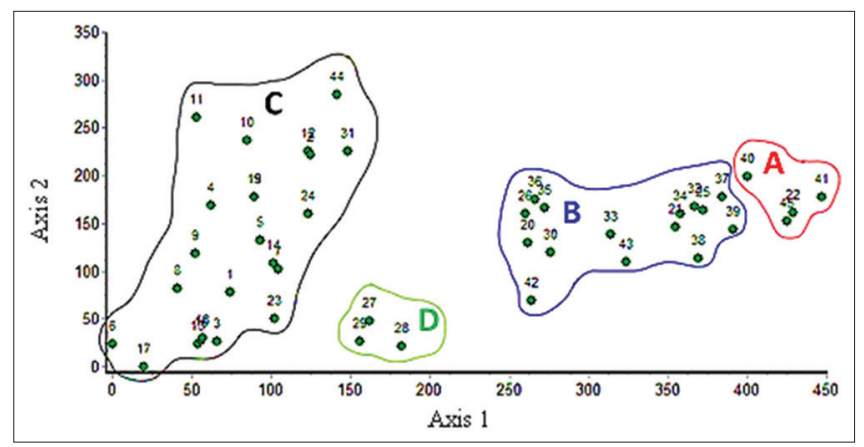

Figure 4: DCA ordination diagram of the 45 sites on axes 1 and 2 within vegetation groups $(A-D)$

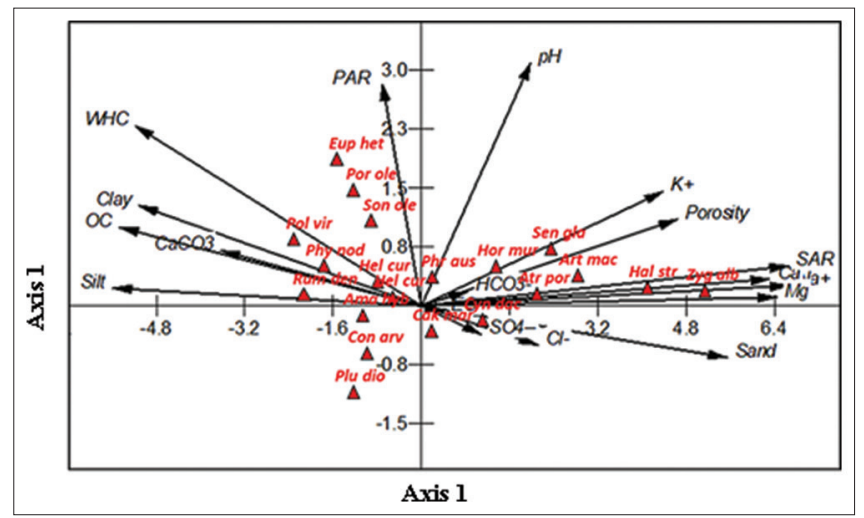

Figure 5: Canonical Correspondence Analysis (CCA) ordination diagram of plant species with soil variables represented by arrows in the study area. The dominant and important species are abbreviated to the first three letters of the genus and species respectively (See Table 2) cations $\left(\mathrm{Na}^{+}, \mathrm{K}^{+}, \mathrm{Ca}^{++}\right.$, and $\left.\mathrm{Mg}^{++}\right)$, and SAR were obviously the most influencing soil parameters with strong significant relationships with the first and second axis. This agrees more or less with the findings of Maswada and Elzaawely (2013), El-Amier et al. (2014a) and Abd-ElGawad et al. (2020) in the Mediterranean area of the Nile Delta.

In the upper right side of the CCA diagram, P. australis, which was the dominant species in group D and important species (A. macrostachyum, A. portulacoides, H. strobilaceum, Z. albam, H. murinum and $\mathrm{S}$. glaucus) in groups $\mathrm{C}$ and $\mathrm{D}$ showed close relationships with sand, $\mathrm{pH}$, cations $\left(\mathrm{Na}^{+}, \mathrm{K}^{+}, \mathrm{Ca}^{++}\right.$, and $\mathrm{Mg}^{++}$) and SAR. In the upper left side of the diagram, P. viridis was the dominant species in group A, H. curassavicum, which was dominant and codominant species in groups $\mathrm{B}$ and $\mathrm{C}$, respectively, and important species (E. heterophylla, P. nodiflora, P. olerceus, R. dentatus and S. oleracous) in groups A and B, all expressed a close relationship with fine fractions (silt and clay), WHC, organic carbon, $\mathrm{CaCO}_{3}$ and PAR. While the codominant species (C. dactylon) and important species (C. maritima) of group $\mathrm{C}$ are separated at the lower right side of the diagram. These species expressed a clear relationship with sand, $\mathrm{SO}_{4}{ }^{2-}$ and $\mathrm{Cl}^{-}$. Meanwhile, in the lower left side, C. arvensis and P. dioscoridis, which were important species in groups B and D, exhibited no relationships with soil factors.

\section{CONCLUSIONS}

Invasive plant species can obstruct native plant establishment and growth, as well as have an influence on soil cover, nutrient cycling, and hydrology. Controlling invasive species is thus vital, although sometimes costly, step toward ecosystem restoration. The current study analyzed the vegetation structure and soil properties of a single invasive plant in the Nile Delta of Egypt in order to aid in the ecological management and protection of these natural resources. More study on modifying soil biota and species diversity to improve invasion resistance is also needed.

\section{AUTHOR'S CONTRIBUTION}

All authors contributed equality in carrying out the research study and the development of this paper.

\section{REFERENCES}

Abd El-Gawad, A. M., \& Shehata, H. S. (2014). Ecology and development of Mesembryanthemum crystallinum L. in the Deltaic Mediterranean coast of Egypt. Egyptian Journal of Basic and Applied Sciences, 1(1), 29-37. https://doi.org/10.1016/j.ejbas.2014.02.003

Abd-ElGawad, A. M., El-Amier, Y. A., Assaeed, A. M., \& Al-Rowaily, S. L. (2020). Interspecific variations in the habitats of Reichardia tingitana (L.) Roth leading to changes in its bioactive constituents and allelopathic activity. Saudi Journal of Biological Sciences, 27(1), 489499. https://doi.org/10.1016/j.sjbs.2019.11.015

Abd-EIGawad, A. M., Elshamy, A. I., Al-Rowaily, S. L., \& El-Amier, Y. A. (2019), Habitat affects the chemical profile, allelopathy, and antioxidant properties of essential oils and phenolic enriched extracts of the invasive plant Heliotropium curassavicum. Plants, 8(11), 482. https:// doi.org/10.3390/plants8110482

Allen, S. E., Grimshaw, H. M., Parkinson, J. A., \& Quarmby, C. (1974). Chemical analysis of ecological materials. Blackwell Scientific Publications. 
Al-Shehbaz, I. A. (1991). The genera of Boraginaceae in the southeastern United States. Journal of the Arnold Arboretum, 1, 1-169.

Baessler, C., \& Klotz, S., (2006). Effects of changes in agricultural land-use on landscape structure and arable weed vegetation over the last 50 years. Agriculture, Ecosystems \& Environment, 115(1-4), 43-50. https://doi.org/10.1016/j.agee.2005.12.007

Barakat, A., Mayer-Laigle, C., Solhy, A., Arancon, R. A., De Vries, H., \& Luque, R. (2014). Mechanical pretreatments of lignocellulosic biomass: towards facile and environmentally sound technologies for biofuels production. RSC Advances, 4(89), 48109-48127. https:// doi.org/10.1039/C4RA07568D

Barney, J. N., Tekiela, D. R., Dollete, E. S., \& Tomasek, B. J (2013). What is the "real" impact of invasive plant species? Frontiers in Ecology and the Environment, 11, 322-329. https://doi.org/10.2307/23470484

Boulos, L. (1999-2005). Flora of Egypt. (Vol. 1-4). Al Hadara Publishing, Cairo.

Christenhusz, M. J., \& Byng, J. W. (2016). The number of known plants species in the world and its annual increase. Phytotaxa, 261(3), 201-217. https://doi.org/10.11646/phytotaxa.261.3.1

Einhellig, F. A. (1995). Allelopathy: Current Status and Future Goals; ACS Publications: Washington, DC, USA.

El-Amier, Y. A. (2016). Vegetation structure and soil characteristics of five common geophytes in desert of Egypt. Egyptian Journal of Basic and Applied Sciences, 3(2), 172-186. https://doi.org/10.1016/j. ejbas.2016.03.001

El-Amier, Y. A., \& Abd El-Gawad, A. M. (2017). Plant communities along the international coastal highway of Nile delta, Egypt. Journal of the Science of Food and Agriculture, 1, 117-131. https://doi.org/10.25081/ jsa.2017.v1.47

El-Amier, Y. A., \& El Hayyany, L. Y. (2020). Floristic composition and species diversity of plant communities associated with genus Atriplex in Nile Delta coast, Egypt. Asian Journal of Conservation Biology, 9(1), 11-24.

El-Amier, Y. A., El-Halawany, E. F. \& Abdullah, T. J. (2014a). Composition and diversity of plant communities in sand formations along the northern coast of the Nile Delta in Egypt. Research Journal of Pharmaceutical, Biological and Chemical Sciences, 5(4), 826-847.

El-Amier, Y. A., Abdelghany, A. M. \& Abed Zaid, A. (2014b). Green synthesis and antimicrobial activity of Senecio glaucus-Mediated silver nanoparticles. Research Journal of Pharmaceutical, Biological and Chemical Sciences, 5(5), 631-642.

El-Amier, Y. A., El-Zeiny, A., El-Halawany, E. S. F., Elsayed, A., El-Esawi, M. A., Noureldeen, A., Darwish, H., Al-Barty, A., \& Elagami, S.A. (2021). Environmental and Stress Analysis of Wild Plant Habitat in River Nile Region of Dakahlia Governorate on Basis of Geospatial Techniques. Sustainability, 13(11), 6377. https://doi. org/10.3390/su13116377

El-Demerdash M. A. (1984). Ecological studies on Juncus plants. Unpublished Ph. D. Thesis, Mansoura University, Egypt.

Elshamy, A., Abd-ElGawad, A. M., El-Amier, Y. A., El Gendy, A., \& AlRowaily, S. (2019). Interspecific variation, antioxidant and allelopathic activity of the essential oil from three Launaea species growing naturally in heterogeneous habitats in Egypt. Flavour and Fragrance Journal, 34, 316-328. https://doi.org/10.1002/ffj.3512

El-Sheikh, M. A. (1989). A study of the vegetation- environmental relationships of the Canal Banks of Middle Delta Region. (MSc. Thesis.) Fac. Sci., Tanta Univ., Egypt.

Frick, B., \& Thomas, A. G. (1992). Weed surveys in different tillage systems in south western Ontario field crops. Canadian Journal of Plant Science, 72, 1337-1347. https://doi.org/10.4141/cjps92-166

Gadallah, S. M., Nasser, M. G., Farag, S. M., Elhawary, M. O., \& Hossny, A. (2019). Deroplax silphoides (Thunberg, 1783) (Hemiptera: Heteroptera: Scutelleridae) Invasive Species in Egypt with additional morphological and behavioral data. Zootaxa, 4624(3), 387-396. https:// doi.org/10.11646/zootaxa.4624.3.7

Grime, J. P. (1979). Primary strategies in plants. In Transactions of the Botanical Society of Edinburgh (Vol. 43) 2: pp. 151-160. Taylor \& Francis Group.

Hegazy, A., Mussa, S., \& Farrag, H. (2008). Invasive plant communities in the Nile Delta coast. Global Journal of Environmental Research, 2, 53-61.
Hegazy, A. K. (1994). Trade-off between sexual and vegetative reproduction of the weedy Heliotropium curassavicum. Journal of Arid Environments, 27, 209-220. https://doi.org/10.1006/jare.1994.1059

Hegazy, A. K., Fahmy, G. M., Ali, M. I., \& Gomaa, N. H. (2004). Vegetation diversity in natural and agro-ecosystems of arid lands. Community Ecology, 5, 163-176. https://doi.org/10.1556/ComEc.5.2004.2.3

Heneidy, S. Z. \& Bidak, L. M. (2001). Multipurpose plant species in Bisha, Asir region, southwestern Saudi Arabia. Journal of King Saud University Science, 13, 11-26

Hill, M. O., \& Šmilauer, P. (2005). Win TWINS. TWINSPAN for Windows version, 2.

Jackson, K. A. (1962). On the origin of dislocations. Philosophical Magazine, 7(81), 1615-1616. https://doi.org/10.1080/14786435808244398

Jackson, S. D. (2000). Overview of Transportation Impacts on Wildlife Movement and Populations. Pp. 7-20 In Messmer, T. A., \& B. West, (Eds) Wildlife and Highways: Seeking Solutions to an Ecological and Socio-economic Dilemma. The Wildlife Society.

Kowarik, I. (1985). Grundlagen der Stadukologie und Forderungen Anchihrer Berucksichtigug bri der Stadgestaltung am Beispiel Berlins, Schriftenrh. DBV. Jungend, 3, 22-39.

Maswada, H. F., \& Elzaawely, A. A. (2013). Ecological investigation of three geophytes in the Deltaic Mediterranean coast of Egypt. Pakistan Journal of Biological Sciences, 16, 1662-1674. https://doi. org/10.3923/pjbs.2013.1662.1674

Negm, A. M., Saavedra, O., \& El-Adawy, A. (2016). Nile Delta biography: Challenges and opportunities. In The Nile Delta; Negm, A.M., Ed.; Springer: Cham, Switzerland, pp. 3-18.

Pierce, W. C., Haenisch, E. L., \& Sawyer, D. T. (1958). Quantitative Analysis. Wiley Toppen, Tokyo.

Pinke, G., Pal, R., \& Botta-Dukat Z. (2010). Effects of environmental factors on weed species composition of cereal and stubble fields in western Hungary. Central European Journal of Biology, 5, 283-292. https:// doi.org/10.2478/s11535-009-0079-0

Piper, C. S. (1947). Mechanical analysis. Soil and Plant Analysis, 368.

Raunkięr, C. (1934-1937). Plant life forms: Clarendon Press.

Shaltout, K. H., Sharaf El-Din, A., \& El-Sheikh, M. A. (1994). Species richness and phenology of vegetation along irrigation canals and drains in the Nile Delta, Egypt. Vegetatio, 112, 35-43. https://doi.org/10.1007/ BF00045098

Shaltout, K. H., Hosni, H. A., El-Kady, H. F., El-Beheiry, M. A. \& Shaltout, S. K. (2016). Composition and pattern of alien species in the Egyptian flora. Flora-Morphology, Distribution, Functional Ecology of Plants, 222, 104-110. https://doi.org/10.1016/j.flora.2016.04.001

Shukla, R. S., \& Chandel, P. S. (1989). A Textbook of Plant Ecology including Ethobotany and Soil science. $10^{\text {th }}$ edition, S. Chand \& Company Ltd., New Delhi.

Spellerberg, I. A. N. (1998). Ecological effects of roads and traffic: a literature review. Global Ecology \& Biogeography Letters, 7(5), 317-333. https://doi.org/10.1046/j.1466-822x.1998.00308.x

Tackholm, V. (1974). Student's Flora of Egypt, (2 ${ }^{\text {nd }}$ ed.). Cairo, Egypt: Cairo University Press.

Ter Braak, C. J. F. (1988). Partial canonical correspondence analysis. In Classification and related methods of data analysis: proceedings of the first conference of the International Federation of Classification Societies (IFCS), Technical University of Aachen, FRG, 29 June-1 July 1987, pp. 551-558. North-Holland.

Walters, D. R., \& Keil, D. J. (1996). Vascular plant taxonomy. Kendall Hunt.

Zahran, M.A. \& Willis, A.J. (2009). The Vegetation of Egypt. Springer. Netherlands

Zheng, Y. L., Feng, Y. L., Zhang, L. K., Callaway, R. M., Valiente-Banuet, A., Luo, D. Q., Liao, Z. Y., Lei, Y. B., Barclay, G. F., \& Silva-Pereyra, C. (2015). Integrating novel chemical weapons and evolutionarily increased competitive ability in success of a tropical invader. The New phytologist, 205(3), 1350-1359. https://doi.org/10.1111/nph.13135

Zohary, D. (1972). The wild progenitor and the place of origin of the cultivated lentil: Lens culinaris. Economic Botany, 26(4), 326-332. https://doi.org/10.1007/BF02860702

Zohary, M. (1966). Flora Palaestina, part 1. Israel Academy of Sciences and Humanities, Jerusalem: 76 


\section{APPENDIX}

Appendix 1: Floristic composition of the plant species of the different habitats in the study area

\begin{tabular}{|c|c|c|c|c|c|c|}
\hline \multirow[t]{2}{*}{ Species } & \multirow[t]{2}{*}{ Family } & \multirow[t]{2}{*}{ Life form } & \multirow[t]{2}{*}{ Chorotype } & \multicolumn{2}{|c|}{ Phytogeographical regions } & \multirow[t]{2}{*}{$\mathrm{P} \%$} \\
\hline & & & & Coastal & Inland & \\
\hline \multicolumn{7}{|l|}{ Perennials } \\
\hline Alhagi graecorum Boiss. & Fabaceae & $\mathrm{H}$ & PAL & + & - & 4.44 \\
\hline $\begin{array}{l}\text { Arthrocnemum macrostachyum (Morocco.) } \\
\text { K.koch }\end{array}$ & Chenopodiaceae & $\mathrm{Ch}$ & $M E+S A-S I$ & + & - & 8.89 \\
\hline Atriplex portulacoides L. & Chenopodiaceae & $\mathrm{Ch}$ & $M E+I R-T R+E R-S R$ & + & - & 8.89 \\
\hline Atriplex semibaccata R.Br. & Chenopodiaceae & $\mathrm{H}$ & AUST & + & - & 6.67 \\
\hline Calligonum comosum ( $\mathrm{L}$, Her.) Soskov. & Polygonaceae & $\mathrm{Nph}$ & SA-SI+IR-TR & + & - & 6.67 \\
\hline Cistanche phelypaea (L.) Cout. & Orobanchaceae & $G, P$ & $M E+S A-S I$ & + & - & 6.67 \\
\hline Convolvulus arvensis $\mathrm{L}$. & Convolvulaceae & $\mathrm{H}$ & $\cos M$ & + & + & 17.78 \\
\hline Cynanchum acutum L. & Asclepiadaceae & $\mathrm{H}$ & $M E+I R-T R$ & + & + & 15.56 \\
\hline Cynodon dactylon (L.) Pers. & Poaceae & G & PAN & + & + & 55.56 \\
\hline Cyperus rotundus L. & Cyperaceae & G & PAN & + & + & 11.11 \\
\hline Cyperus articulatus L. & Cyperaceae & $\mathrm{G}, \mathrm{He}$ & PAN & - & + & 2.22 \\
\hline Cyperus capitatus Vand. & Cyperaceae & G & $\mathrm{ME}$ & + & - & 2.22 \\
\hline Echinochloa stagnina (Retz.) P.Beauv. & Poaceae & $\mathrm{G}, \mathrm{He}$ & PAL & - & + & 2.22 \\
\hline Echinopus spinosus L. & Asteraceae & $\mathrm{H}$ & $M E+S A-S I$ & + & - & 13.33 \\
\hline Halocnemum strobilaceum (Pall.) M. Bieb. & Chenopodiaceae & $\mathrm{Ch}$ & $M E+I R-T R+S A-S I$ & + & - & 4.44 \\
\hline Heliotropium curassavicum L. & Boraginaceae & $\mathrm{Ch}$ & NEO & + & + & 100 \\
\hline Imperata cylindrica (L.) Raeusch & Poaceae & $\mathrm{H}$ & $M E+P A L$ & + & + & 11.11 \\
\hline Juncus acutus L. & Juncaceae & $\mathrm{He}$ & $M E+I R-T R+E R-S R$ & + & - & 6.67 \\
\hline Limbarda crithmoides (L). Dumort. & Asteraceae & $\mathrm{Ch}$ & $M E+E R-S R+S A-S I$ & + & - & 6.67 \\
\hline Launaea mucronata (Forssk.) Muschl. & Asteraceae & $\mathrm{H}$ & $\mathrm{ME}+\mathrm{SA}-\mathrm{SI}$ & + & - & 6.67 \\
\hline Launaea nudicaulis (L.) Hook.f. & Asteraceae & $\mathrm{H}$ & SA-SI & + & - & 4.44 \\
\hline Leptochloa fusca (L.) Kunth. & Poaceae & $\mathrm{G}, \mathrm{He}$ & PAN & + & + & 6.67 \\
\hline Lolium perenne L. & Poaceae & Th & $M E+I R-T R+E R-S R$ & + & + & 17.78 \\
\hline Lotus polyphllos E.D.Clarke. & Fabaceae & Th & $\mathrm{ME}$ & + & - & 2.22 \\
\hline Mentha longifolia (L.) Huds. & Lamiaceae & $\mathrm{H}$ & PAL & - & + & 2.22 \\
\hline Oxalis corniculata $\mathrm{L}$. & Oxalidaceae & $\mathrm{H}$ & COSM & - & + & 8.89 \\
\hline Paspalidium geminatum (Forssk .) Stapf & Poaceae & $\mathrm{He}$ & PAL & - & + & 2.22 \\
\hline Persicaria salicifolia Brouss. ex Willd. & Polygonaceae & $G$ & PAL & - & + & 2.22 \\
\hline Phragmites australis (Cav.) Trin. exSteud. & Poaceae & $\mathrm{G}, \mathrm{He}$ & $\cos M$ & + & + & 40 \\
\hline Phyla nodiflora (L.) Greene & Verbenaceae & $\mathrm{Ch}$ & PAN & + & + & 13.33 \\
\hline Plantago major $\mathrm{L}$. & Plantaginaceae & $\mathrm{H}$ & $\cos M$ & - & + & 4.44 \\
\hline Pluchea dioscoridis (L.) DC. & Asteraceae & Nph & $S A-S I+S-Z$ & - & + & 13.33 \\
\hline Polygonum equsetiforme $\mathrm{Sm}$. & Polygonaceae & G & $M E+I R-T R$ & + & - & 2.22 \\
\hline Stipagrostis lanata (Forssk) De Winter & Poaceae & G & SA-SI & + & - & 2.22 \\
\hline Suaeda pruinosa Lang & Chenopodiaceae & $\mathrm{Ch}$ & ME & + & - & 6.67 \\
\hline Symphyotrichum squamatum (Asch.) Dandy & Asteraceae & $\mathrm{Ch}$ & NEW & + & + & 11.11 \\
\hline Tamarix nilotica (Ehrenb). Bunge & Tamaricaceae & Nph & $S A-S I+S-Z$ & + & + & 4.44 \\
\hline Veronica anagallis-aquatica L. & Scrophulariaceae & $\mathrm{He}$ & $\operatorname{cosm}$ & - & + & 2.22 \\
\hline Zygophyllum aegyptium Hosny & Zygphyllaceae & $\mathrm{Ch}$ & $\mathrm{ME}$ & + & - & 11.11 \\
\hline Zygophyllum albam L.F & Zygphyllaceae & $\mathrm{Ch}$ & $M E+S A-S I$ & + & - & 17.78 \\
\hline \multicolumn{7}{|l|}{ Biennials } \\
\hline Rorippa palustris (L.) Besser, Enum. PI.Volhyn. & Brassicaceae & Th & $M E+I R-T R+E R-S R$ & + & - & 4.44 \\
\hline Spergularia marina (L.) Griseb. & Caryophyllaceae & Th & $M E+I R-T R+E R-S R$ & + & - & 4.44 \\
\hline \multicolumn{7}{|l|}{ Annuals } \\
\hline Aegilops bicornis (Forss) Jaub\&Spach & Poaceae & Th & $M E+S A-S I$ & + & - & 8.89 \\
\hline Amaranthus graecizans L. & Amaranthaceae & Th & $M E+I R-T R$ & - & + & 2.22 \\
\hline Amaranthus hybridus L. & Amaranthaceae & Th & PAL & + & + & 11.11 \\
\hline Amaranthus lividus L. & Amaranthaceae & Th & PAL & + & - & 2.22 \\
\hline Anagallis arvensis L. var. arvensis & Primulaceae & Th & COSM & + & + & 11.11 \\
\hline Anchusa humilis (Desf) I.M.Johnst. & Boraginaceae & Th & $M E+S A-S I$ & + & - & 2.22 \\
\hline Apium leptophyllum (Pers.) F. Muell. Ex.Benth. & Primulaceae & Th & $\cos M$ & + & + & 4.44 \\
\hline Astragalus peregrinus Vahl & Fabaceae & Th & SA-SI & + & - & 2.22 \\
\hline Bassia indica (Wight) Scott. & Chenopodiaceae & Th & IR-TR $+S-Z$ & + & - & 33.33 \\
\hline Bassia muricata (L.) Asch. & Chenopodiaceae & Th & IR-TR+SA-SI & + & - & 4.44 \\
\hline Beta vulgaris var. cicla $L$. & Chenopodiaceae & Th & $M E+I R-T R+E R-S R$ & + & + & 20 \\
\hline Bidens pilosa $\mathrm{L}$. & Asteraceae & Th & PAN & + & + & 24.44 \\
\hline Bromus diandrus Roth & Poaceae & Th & $\mathrm{ME}$ & + & - & 17.78 \\
\hline $\begin{array}{l}\text { Cakile maritima Scop. subsp. aegyptiaca (Willd.) } \\
\text { Nyman }\end{array}$ & Brassicaceae & Th & $M E+E R-S R$ & + & - & 35.56 \\
\hline Calendula arvensis L. & Asteraceae & Th & $\mathrm{ME}+\mathrm{IR}-\mathrm{TR}+\mathrm{SA}-\mathrm{SI}$ & + & - & 2.22 \\
\hline
\end{tabular}


Appendix 1: (Continued)

\begin{tabular}{|c|c|c|c|c|c|c|}
\hline \multirow[t]{2}{*}{ Species } & \multirow[t]{2}{*}{ Family } & \multirow[t]{2}{*}{ Life form } & \multirow[t]{2}{*}{ Chorotype } & \multicolumn{2}{|c|}{ Phytogeographical regions } & \multirow[t]{2}{*}{$\mathrm{P} \%$} \\
\hline & & & & Coastal & Inland & \\
\hline Capsella bursa pastoris (L.) Medk. & Brassicaceae & Th & COSM & - & + & 2.22 \\
\hline Carduus getulus Pomel. & Asteraceae & Th & SA-SI & + & - & 2.22 \\
\hline Carduus pycnocephalus L. & Asteraceae & Th & $\mathrm{ME}$ & + & - & 6.67 \\
\hline Carthamus tenuis (Boiss \& Blanche) Bornm & Asteraceae & Th & $\mathrm{ME}$ & + & - & 2.22 \\
\hline Chenopodium murale L. & Chenopodiaceae & Th & COSM & + & + & 44.44 \\
\hline Conyza aegyptiaca (L.) Dryand & Asteraceae & Th & $\mathrm{ME}$ & + & + & 13.33 \\
\hline Conyza bonariensis (L.) Cronquist, Bull. & Asteraceae & Th & ME & + & + & 4.44 \\
\hline Cornopus didymus (L.) Sm. & Brassicaceae & Th & COSM & - & + & 2.22 \\
\hline Cutandia memphitica (Spreng.) Benth. & Poaceae & Th & $M E+I R-T R+S A-S I$ & + & - & 2.22 \\
\hline Echinochloa colona (L.) Link & Poaceae & Th & PAN & - & + & 4.44 \\
\hline Eclipta alba L. & Asteraceae & Th & NEO & - & + & 2.22 \\
\hline Emex spinosa (L.) Campd. & Polygonaceae & Th & $\mathrm{ME}+\mathrm{SA}-\mathrm{SI}$ & + & + & 4.44 \\
\hline Erodium laciniatum (Cav.) Willd. & Geraniaceae & Th & $\mathrm{ME}$ & + & - & 4.44 \\
\hline Euphorbia peplus L. & Euphorpiaceae & Th & $M E+I R-T R+E R-S R$ & + & + & 15.56 \\
\hline Euphorbia heliscopia L. & Euphorpiaceae & Th & $M E+I R-T R+S A-S I$ & + & + & 4.44 \\
\hline Euphorbia heterophylla L. & Euphorpiaceae & Th & PAN & - & + & 4.44 \\
\hline Euphorbia prostrata Aiton, Hort. Kew, ed. & Euphorpiaceae & Th & PAN & - & + & 2.22 \\
\hline Hordium marinum Huds. & Poaceae & Th & $M E+I R-T R$ & + & - & 24.44 \\
\hline Ifloga spicata (Forssk.) Sch. Bip. & Asteraceae & Th & SA-SI & + & - & 2.22 \\
\hline Juncus rigidus L. & Juncaceae & $\mathrm{G}, \mathrm{He}$ & $M E+I R-T R+E R-S R$ & + & - & 6.67 \\
\hline Lobularia arabica (Boiss.) Muschl. & Brassicaceae & Th & SA-SI & + & - & 2.22 \\
\hline Lotus halophilus Boiss. \& Spruner & Fabaceae & Th & $M E+S A-S I$ & + & - & 6.67 \\
\hline Malva parvifolra L. & Malvaceae & Th & $M E+I R-T R$ & + & + & 37.78 \\
\hline Medicago sativum $\mathrm{L}$. & Fabaceae & Th & COSM & - & + & 2.22 \\
\hline Melilotus indicus (L.) All. & Fabaceae & Th & ME+IR-TR+SA-SI & + & + & 15.56 \\
\hline Mesembryanthemum crystallinum $\mathrm{L}$. & Aizoaceae & Th & $M E+E R-S R$ & + & - & 31.11 \\
\hline Mesembryanthemum nodiflorum L. & Aizoaceae & Th & $\mathrm{ME}+\mathrm{SA}-\mathrm{SI}+\mathrm{ER}-\mathrm{SR}$ & + & - & 15.56 \\
\hline Parapholis incurva (L.) C.E. Hubb & Poaceae & Th & $M E+I R-T R+E R-S R$ & + & - & 11.11 \\
\hline Phalaris minor Retz. & Poaceae & Th & $M E+I R-T R$ & - & + & 2.22 \\
\hline Plantago lagopus L. & Plantaginaceae & Th & $M E+I R-T R$ & + & - & 2.22 \\
\hline Plantago squarrosa Murray & Plantaginaceae & Th & $\mathrm{ME}$ & + & - & 2.22 \\
\hline Poa annua L. & Poaceae & Th & COSM & + & + & 13.33 \\
\hline Portulaca oleracea L. & Portulacaea & Th & IR-TR + SA-SI & + & + & 13.33 \\
\hline Polypogon monspeliensis (L.) Desf. & Poaceae & Th & $\cos M$ & + & + & 13.33 \\
\hline Polypogon viridis (Gouan) Breistr. & Poaceae & $\mathrm{H}$ & $M E+I R-T R$ & + & + & 22.22 \\
\hline $\begin{array}{l}\text { Pseudognaphalium luteo-album (L.) Hlliard\& } \\
\text { B.L. Burtt. }\end{array}$ & Asteraceae & Th & Cosm & - & + & 2.22 \\
\hline Reichardia tingitana (L.) Roth & Asteraceae & Th & $M E+I R-T R$ & + & - & 17.78 \\
\hline Rumex dentatus L. & Polygonaceae & Th & $M E+I R-T R+E R-S R$ & - & + & 15.56 \\
\hline Rumex pictus Forssk. & Polygonaceae & Th & $\mathrm{ME}+\mathrm{SA}-\mathrm{SI}$ & + & - & 22.22 \\
\hline Salsola kali L. & Chenopodiaceae & Th & $\cos M$ & + & - & 20 \\
\hline Senecio aegyptius $\mathrm{L}$. & Asteraceae & Th & $M E+I R-T R+E R-S R$ & - & + & 2.22 \\
\hline Senecio glaucus L. & Asteraceae & Th & $M E+I R-T R+S A-S I$ & + & + & 37.78 \\
\hline Setaria verticillata (L.) P. Beauv. & Asteraceae & Th & $\cos M$ & - & + & 2.22 \\
\hline Silene vivianii Steud. & Caryophyllaceae & Th & SA-SI & + & - & 2.22 \\
\hline Sisymbrium irio L. & Brassicaceae & Th & $M E+I R-T R+E R-S R$ & + & + & 6.67 \\
\hline Solanum nigrum $\mathrm{L}$. & Solanaceae & Th & $\cos M$ & + & + & 22.22 \\
\hline Sonchus oleraceus L. & Asteraceae & Th & COSM & + & + & 35.56 \\
\hline Stellaria pallida (Dumort.) Murb. & Caryophyllaceae & Th & $M E+E R-S R$ & + & + & 6.67 \\
\hline Suaeda maritima (L) Dumort. & Chenopodiaceae & Th & $\cos M$ & + & - & 4.44 \\
\hline Urospermum picroides (L.) F.W.Schmidt & Asteraceae & Th & $M E+I R-T R$ & + & + & 6.67 \\
\hline Urtica urens $L$. & Urticaceae & Th & $M E+I R-T R+E R-S R$ & + & + & 11.11 \\
\hline Vicia sativa L. & Fabaceae & Th & $M E+I R-T R+E R-S R$ & + & + & 8.89 \\
\hline
\end{tabular}

$\mathrm{P}=$ Presence, $\mathrm{Nph}=$ Phanerophytes, $\mathrm{H}=$ Hemicryptophyte, $\mathrm{Ch}=$ Chemaephytes, $\mathrm{Th}=$ Theophytes, $\mathrm{G}=$ Geophytes, He $=$ Helophytes, $\mathrm{P}=$ Parasites, SA-SI = Saharo-Sindian, S-Z = Sudano-Zambezian, IR-TR = Irano-Turanian, ER-SR = Euro-Siberian, ME = Mediterranean, NE0 = Neotropical, PAL $=$ Palaeotropical, PAN $=$ Pantropical, COSM $=$ Cosmopolitan, AUST $=$ Australian 